\title{
English Breakfast Program: Cara Mudah Pintar Berbahasa Inggris
}

\author{
English Breakfast Program: The Easy Way To Be Smart In English \\ ${ }^{1)}$ Yuli Agustina, ${ }^{2 *}$ Raqqasyi Rahmatullah Musafir, ${ }^{3)}$ Agung Winarto \\ ${ }^{1,2,3)}$ Universitas Negeri Malang \\ Jalan Semarang 5, Malang 65145 Jawa Timur, Indonesia \\ *email: dannyasmawan@gmail.com
}

DOI:

10.30595/jppm.v5i1.6902

Histori Artikel:

Diajukan:

03/03/2020

Diterima:

$01 / 04 / 2021$

Diterbitkan:

$14 / 04 / 2021$

\section{ABSTRAK}

Tujuan dilaksanakan program English Breakfast (EB) untuk membantu siswa meningkatkan kemampuan berbahasa Inggris melalui pemberian kosa kata bahasa Inggris secara rutin yang nantinya berdampak terhadap hasil belajar siswa khususnya siswa Suntisart Wittaya School, Kabang District, Yala Province, Thailand. Program ini dilaksanakan sebanyak 3-4 kali setiap minggu dengan alokasi waktu 8-9 menit di pagi hari. Tahap-tahap yang dilakukan pada program ini yaitu: perencanaan, persiapan, pelaksanaan, pengamatan, dan refleksi. Adapun metode yang dilakukan dalam pelaksanaan EB yakni tanya jawab antara guru dengan siswa menggunakan berbagai media visual. Program English Breakfast menghasilkan data banyaknya kosa kata yang diberikan pada setiap pertemuan. Selain itu, pengaruh program English Breakfast terhadap pembelajaran juga menghasilkan data rata-rata nilai harian siswa pada mata pelajaran English Conversation setelah pelaksanaan program English Breakfast. Program ini berjalan dengan lancar dan berdampak positif terhadap hasil belajar siswa pada mata pelajaran English Conversation. Jika program ini terus dilaksanakan secara rutin, maka kemampuan bahasa Inggris siswa semakin meningkat. Akibatnya, hasil belajar siswa pada mata pelajaran English Conversation juga menjadi optimal.

Kata kunci: Bahasa Inggris; Conversation; English Breakfast Program; Pronunciation

\begin{abstract}
The purpose of the English Breakfast $(E B)$ program is to help students improve their English language skills through the provision English vocabularies routinely which will have an impact on students learning outcomes especially students of Suntisart Wittaya School, Kabang District, Yala Province, Thailand. The program is carried out 3-4 times each week with time allocation is 8-9 minutes in the morning. The steps carried out in this program are: planning, preparation, implementation, observation, and reflection. The method used in implementation of EB is question and answer between the teacher and students using various visual media. The English Breakfast program generates data on the amount of vocabulary given at each meeting. In addition, the effect of the English Breakfast program on learning also produces data on average daily scores of students in English Conversation subjects after the implementation of the English Breakfast program. By analyzing the data using Minitab 17 software, this program is carried out smoothly and has a positive impact on student learning outcomes in English Conversation subjects. If this program continues to be carried out routinely, then the students' English ability will increase. As a result, student learning outcomes in English Conversation subjects are also optimal.
\end{abstract}

Keywords: English; Conversation; English Breakfast Program; Pronunciation 


\section{PENDAHULUAN}

Masyarakat Thailand Selatan khususnya di lingkungan Suntisart Wittaya School menggunakan bahasa Melayu Pattani sebagai bahasa sehari-hari mereka. Jika ditinjau dari segi bahasa yang siswa pelajari di sekolah, maka bahasa yang dipelajari di sekolah antara lain bahasa Inggris, bahasa Arab, bahasa Rumi (Melayu), dan bahasa Thailand. Selain itu, siswa juga mempelajari berbagai macam tulisan diantaranya Alfabet, Arab, Arab Melayu, dan Thailand. Ragamnya bahasa dan tulisan yang dipelajari siswa di sekolah mengakibatkan kesulitan siswa dalam mempelajari semua bahasa tersebut sekaligus. Selain itu, ketika pelaksanaan pembelajaran English Conversation banyak siswa yang mengeluh bahwa bahasa Inggris merupakan pelajaran yang sulit. Oleh karena itu, kemampuan bahasa Inggris siswa di Suntisart Wittaya School masih rendah karena kesulitan berbahasa Inggris.

Menurut Astutie (2018), kesulitan yang dialami siswa dalam berbahasa Inggris yaitu kosa kata dan pelafalannya. Sehingga kualitas kemampuan berbahasa Inggris siswa salah satunya dapat dinilai dari ketepatan pengucapan dan pemaknaan terhadap suatu kata. Pengucapan atau pronunciation siswa masih banyak kesalahan karena sebagian besar siswa-siswi di sekolah masih kesulitan dalam membaca kosa kata bahasa Inggris. Hal ini salah satunya dapat disebabkan oleh pembelajaran bahasa di sekolah yang beragam sehingga siswa kesulitan dalam menemukan penyesuaian bahasa. Penyesuaian dalam berbahasa Inggris dapat diatasi dengan melakukan conversation secara rutin. Akan tetapi, kemungkinan besar permasalahan yang muncul adalah kesulitan dalam menulis kalimat yang diucapkan. Sebab menulis kalimat bahasa Inggris erat kaitannya dengan ejaan kata/kalimat (Windarti \& Budiningsih, 2016). Oleh karena itu, struktur kata bahasa Inggris sangat diperlukan untuk meningkatkan kemampuan membaca dan mengucapkan kalimat berbahasa Inggris.

Kesulitan siswa dalam membaca mengakibatkan kurangnya kosa kata yang dimiliki siswa. Kuantitas kosa kata merupakan faktor yang menentukan kemampuan berbahasa Inggris siswa (Yarmi \& Atika, 2015). Supaya siswa memiliki kesempatan untuk berbahasa Inggris yang baik, maka kosa kata siswa perlu diperbanyak dan diperbaiki. Untuk memperbanyak kosa kata yang dimiliki siswa, perlu diberikan pengalaman dan hafalan secara rutin. Pengalaman dan hafalan yang dilakukan siswa perlu dukungan dan bimbingan dari seorang guru yang mampu mengarahkan siswa melalui metode pembelajaran yang sesuai dengan kondisi siswa.

Salah satu yang mendukung pelaksanaan pembelajaran yaitu metode pembelajaran. Metode pembelajaran yang digunakan di Suntisart Wittaya School masih konvensional yaitu metode ekspositori (Teacher Centered Approach) dimana siswa tidak turut aktif ketika pembelajaran berlangsung (Yarmi \& Atika, 2015). Ketika siswa tidak turut aktif maka pembelajaran hanya terjadi satu arah. Padahal pembelajaran bahasa Inggris harus terjadi dua arah sehingga siswa tidak hanya paham terhadap kata yang dipelajari tetapi juga memiliki pengetahuan terhadap struktur, bentuk, dan ejaan dari suatu kata (Julia et al., 2018). Selain itu, siswa yang sedang melaksanakan pembelajaran dua arah tidak merasa bosan dan mendapatkan pemahaman materi dengan baik.

Pemahaman materi bahasa Inggris yang baik dapat dinilai dari segi membaca, menulis, mendengarkan/ menyimak, dan berbicara (Windarti \& Budiningsih, 2016). Untuk memenuhi semua karakteristik penilaian tersebut, diperlukan latihan yang rutin kepada siswa. Sebagai contoh, kemampuan baca (Reading) dapat menggunakan latihan bimbing bacara bahasa Inggris. Kemampuan menulis (Writing) dapat menggunakan latihan bagaimana susunan/struktur kata yang diberikan. Kemampuan mendengar (Listening) dapat menggunakan metode ceramah atau eksposetori. Kemampuan berbicara (Speaking) dapat menggunakan latihan secara rutin hingga terbiasa. Empat keterampilan dalam bahasa Inggris siswa tersebut dapat dimiliki dengan melakukan kegiatan English Breakfast yang dilakukan di sekolah khususnya Suntisart Wittaya School. 
Dari pemaparan di atas dapat dirangkum beberapa permasalahan yaitu kualitas kosa kata bahasa Inggris siswa sekolah dasar (phratom) di Suntisart Wittaya School yang masih rendah terlihat bahwa masih banyak siswa-siswi yang tidak bisa membaca dan berbicara menggunakan bahasa Inggris. Kemudian kemampuan menulis dan mendengar masih relatif rendah dikarenakan siswa tidak berlatih secara rutin dalam berbahasa Inggris. Melalui program English Breakfast siswa akan belajar kosa kata bahasa Inggris di pagi hari sebagai alternatif untuk menyelesaikan permasalahan siswa yang ada di sekolah.

\section{METODE}

Program English Breakfast (EB) dilaksanakan secara rutin dengan menggunakan metode tanya jawab di luar kelas antara siswa dengan guru. Peserta yang terlibat dalam program ini adalah mahasiswa KKN dan siswa-siswi phratom kelas 2-6. Program dilaksanakan sebanyak 3-4 kali setiap minggu selama 8-9 menit setelah senam pagi. Selain itu, tempat pelaksanaan program ini yaitu halaman Suntisart Wittaya School. Hal iki karena halaman sekolah memiliki tempat yang cukup lapang sehingga dapat diperhatikan oleh siswa. Selain itu halaman sekolah merupakan tempat siswa berbaris di pagi hari sehingga memiliki keteraturan ketika terdapat peserta yang keluar dari kegiatan dikarenakan kondisi yang kurang baik (Robertson, 2017). Sehingga akses jalan siswa ketika meninggalkan tempat pelaksanaan tidak mengganggu kegiatan pada program ini.

Program ini merupakan pembelajaran dua arah dimana guru memberikan pertanyaan yang dijawab oleh siswa. Aktivitas tanya jawab memiliki ruang lingkup kosa kata yang berbeda di setiap kegiatan. Sehingga perlu dipersiapkan untuk program ini. Oleh karena itu, program ini memiliki beberapa tahapan yakni tahap perencanaan, tahap persiapan, tahap pelaksanaan, tahap pengamatan ,dan tahap refleksi.

Pada tahap perencanaan, hal yang perlu dipersiapkan yaitu materi yang digunakan ketika program berlangsung supaya dapat dilaksanakan dengan hambatan yang minimum. Selain itu, faktor pendukung dari materi yaitu media yang digunakan. Media yang digunakan berupa gambar objek dua dimensi atau benda manipulatif. Penggunakaan objek dua dimensi atau gambar ketika objek susah dicari dan ditunjukkan. Sedangkan benda manipulatif digunakan ketika mudah untuk ditunjukkan kepada siswa. Ukuran objek yang digunakan kurang lebih $700 \mathrm{~cm}^{2}$ supaya siswa dapat melihat dengan baik.

Pada tahap persiapan, media yang telah direncakan sebelumnya kemudian dicetak atau dipersiapkan. Media yang digunakan berbeda-beda setiap kegiatan tergantung materi yang digunakan. Sehingga tidak semua benda dari materi yang digunakan merupakan benda manipulatif. Materi yang digunakan pada program ini merupakan materi yang sudah dikenal siswa setiap harinya. Setelah materi dan media telah dipersiapkan, maka dilanjutkan ke tahap pelaksanaan.

Setelah semua alat dan bahan kegiatan dipersiapkan, tahap selanjutnya ialah tahap pelaksanaan. Program English Breakfast dilaksanakan dengan beberapa kegiatan yaitu dimulai dengan pembukaan. Ketika pembukaan, guru mengucapkan salam, keadaan siswa, dan sedikit berbincang dengan siswa menggunakan bahasa Inggris. Hal ini dilakukan supaya siswa mendapatkan sedikit pemanasan untuk kegiatan inti. Kegiatan inti dimana dibagi kembali menjadi dua subkegiatan yakni kegiatan kosa kata (vocabularies) dan kegiatan pelafalan (pronunciation). Kegiatan kosa kata yaitu kegiatan dimana guru menunjukkan beberapa benda/gambar benda kepada siswa untuk disebutkan. Setelah kegiatan kosa kata, dilanjutkan dengan kegiatan pengejaan. Guru meminta siswa untuk menyebutkan huruf pembentuk kata. Kegiatan pengejaan meminta siswa menyebutkan huruf pembentuk kata sampai semua siswa menyebutkan dengan benar. Terkadang guru meminta semua siswa dari salah satu kelas untuk menyebutkan kata bendanya berserta ejaannya. Setelah serangkaian kegiatan inti dilakukan, kemudian guru memberikan beberapa pertanyaan untuk refleksi siswa terhadap apa yang telah diperoleh. 
Pada tahap pengamatan, subyek pengamatan yang digunakan oleh mahasiswa yaitu siswa kelas 4/1. Pengamatan yang dilakukan untuk melihat perkembangan kosa kata siswa kelas 4/1 setiap program $E B$ telah dilaksanakan. Perkembangan kosa kata siswa ditentukan dari kecepatan respon dan pengucapan siswa. Siswa dapat merespon dengan cepat ketika siswa memiliki hafalan kosa kata yang banyak dan memiliki wawasan yang luas terhadap suatu objek. Ketika siswa diminta untuk menentukan bahasa inggris dari suatu benda, siswa harus mengerti terlebih dahulu apa benda yang diminta. Jika siswa memiliki wawasan yang luas, maka akan cepat dalam mengerti benda yang diminta. Kemudian siswa mengucapkan kosa kata bahasa Inggris yang salah satunya ditentukan oleh kebiasaan siswa dalam berbicara. Hasil dari pengamatan ini berupa data-data yang nantinya akan dianalisis menggunakan software minitab 17.

Tahap refleksi dilakukan setelah melakukan kegiatan inti beserta rangkaiannya. Tujuan refleksi kegiatan adalah supaya kegiatan yang akan datang menjadi lebih berkembang daripada yang telah dilakukan (Utami, 2015). Refleksi dilakukan pada tiga tahap awal yakni perencanaan, persiapan, dan kegiatan. Refleksi kegiatan ini juga diikuti oleh beberapa pihak yaitu kepala sekolah, pihak akademik sekolah, dan guru pembimbing. Hal ini dilakukan karena rencana yang telah disusun di awal tidak semestinya sama dengan kenyataan ketika kegiatan berlangsung. Sehingga perlu diadakan masukan-masukan terhadap kegiatan untuk memperbaiki kesalahan yang dilakukan sebelumnya (Sunardi \& Sujadi, 2017). Teknik refleksi pembelajaran yaitu penilaian peserta didik kepada guru, evaluasi proses dan hasil belajar, diagnosis kesulitan siswa, dan penilaian antar guru (Sunardi \& Sujadi, 2017). Teknik yang pertama yakni penilaian dari peserta didik kepada guru dengan memberikan interview singkat tentang kegiatan English Breakfast yang telah dilaksanakan. Kemudian guru menilai proses kegiatan $E B$ apakah akibat, kekurangan, kelebihan dari suatu kegiatan kepada siswa. Setelah itu, guru menduga kesulitan siswa ketika berdasarkan penilaian sebelumnya. Ketika tidak memiliki alternatif penyelesaian tentang kesulitan siswa, maka guru dapat berdiskusi dengan ketua bidang akademik dan kepada sekolah.

\section{HASIL DAN PEMBAHASAN}

\section{Program Englishh Breakfast} dipersiapkan dengan menggunakan materimateri yang berkaitan dengan benda atau aktivifitas yang dilakukan siswa. Seperti nama-nama ATK, nama-nama pakaian, macam-macam hewan, macam-macam tumbuhan, macam-macam makanan, macammacam benda yang dibawa guru, dan macammacam penampilan. Dari materi tersebut, dipersiapkan media yang akan digunakan dalam program English Breakfast baik berupa benda manipulatif maupun media cetak. Media yang dipersiapkan cukup mudah yaitu media manipulatif yang ada atau media cetak dibuat dengan memanfaatkan berbagai fasilitas sekolah yaitu komputer, kertas, dan printer. Setelah perencanaan dan persiapan dilakukan, maka program ini siap untuk dilaksanakan.

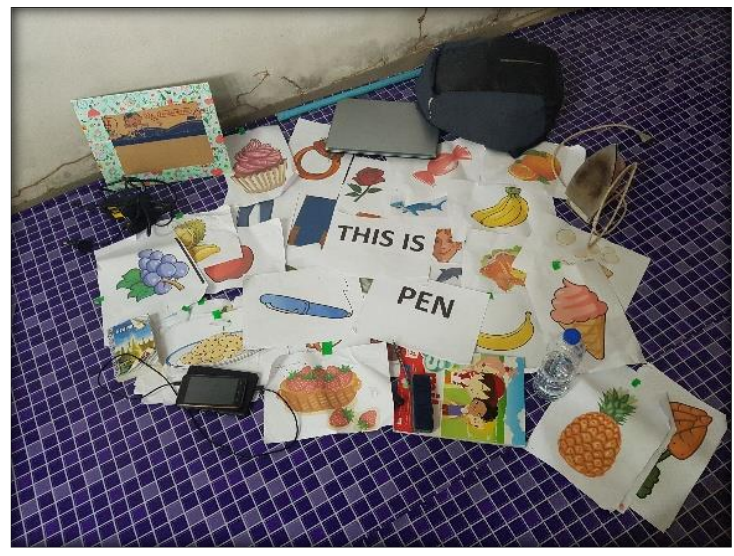

Gambar 1. Media English Breakfast Program

Pelaksanaan English Breakfast terdiri dari kegiatan kosa kata dan kegiatan pelafalan. Kedua kegiatan tersebut dilaksanakan dengan lancar dan teratur. Beberapa kondisi dan solusi ketika melaksanakan program English Breakfast diantaranya: (i) jika tidak ada satupun siswa yang dapat menyebutkan dan melafalkan gambar/benda yang ditunjukkan, maka guru memberi tahu nama benda atau gambar yang ditunjukkan; (ii) jika ada sedikit siswa yang dapat menyebutkan dan melafalkan, maka guru meminta siswa tersebut 
menyebutkan dan melafalkan kembali dengan suara yang keras diikuti dengan siswa yang lainnya; dan (iii) jika semua siswa dapat menyebutkan dan melafalkan nama benda/gambar yang tunjukkan, maka dilanjutkan untuk benda selanjutnya. Sehingga kegiatan pemberian kosa kata dan pelafalan bergantung pada banyaknya kosa kata yang diberikan pada suatu pertemuan. Oleh karena itu, keberhasilan program pada suatu pertemuan bergantung pada banyaknya kosa kata yang diperoleh siswa melalui bimbingan guru.

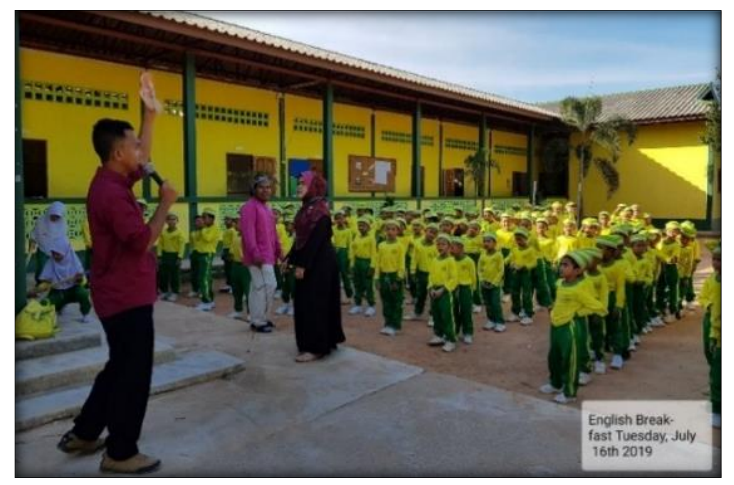

Gambar 2. Kegiatan Kosa Kata pada $E B$ Program

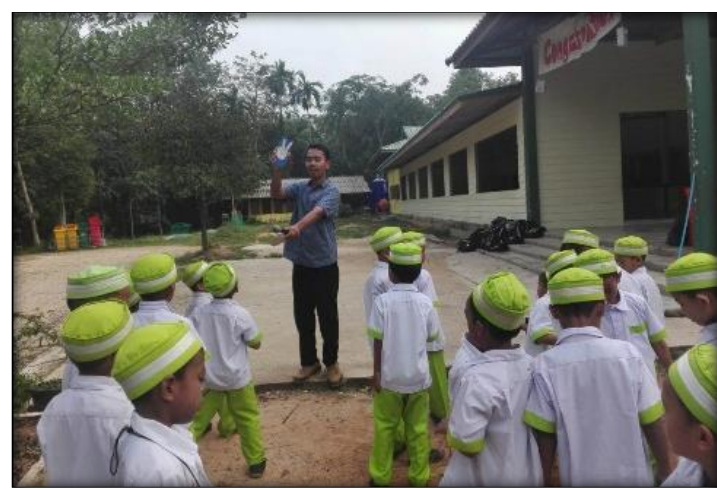

Gambar 3. Kegiatan Pelafalan pada English Breakfast Program

Program English Breakfast memiliki pengaruh terhadap kosa kata bahasa Inggris siswa serta hasil belajar siswa di kelas terutama pada mata pelajaran English Conversation. Hal ini diperiksa berdasarkan kelancaran program English Breakfast setelah beberapa kali dilakukan dan pengaruhnya terhadap hasil KBM conversation di kelas khususnya kelas 4/1. Kelancaran kegiatan
English Breakfast ditentukan dari banyaknya kosa kata yang didapatkan selama 8-9 menit selama 14 pertemuan pertama.

Pada tabel 1 disediakan banyaknya kosa yang diterima siswa $\left(\mathrm{Y}_{1}\right)$ pada 14 pertemuan $\left(\mathrm{X}_{1}\right)$.

Tabel 1. Hasil Kegiatan Program $E B$

\begin{tabular}{cc}
\hline Pertemuan $\left(\mathrm{X}_{1}\right)$ & $\begin{array}{c}\text { Banyak kosa kata } \\
\text { setiap pertemuan } \\
\left(\mathrm{Y}_{1}\right)\end{array}$ \\
\hline 1 & 3 \\
2 & 3 \\
3 & 4 \\
4 & 5 \\
5 & 4 \\
6 & 5 \\
7 & 6 \\
8 & 6 \\
9 & 7 \\
10 & 8 \\
11 & 9 \\
12 & 8 \\
13 & 9 \\
14 & 9 \\
\hline
\end{tabular}

Menggunakan software minitab 17 dengan $\alpha=0,05$ diperoleh persamaan regresi liniernya $Y_{1}=2,29+0,514 X_{1} \quad$ dengan $R_{S q}=94,4 \%$. Karena gradien persamaan garis hubungan antara $\mathrm{X}$ dan $\mathrm{Y}_{1}$ bernilai positif (yakni 0,514) sehingga semakin sering dilaksanakan program $E B$ maka kegiatannya semakin lancar. Akibatnya kemampuan siswa semakin lama semakin baik. Hasil dari kelancaran kegiatan English Breakfast juga berpengaruh terhadap hasil pembelajaran di kelas khususnya siswa kelas $4 / 1$. Hal ini dapat 
dilihat nilai harian 32 siswa dan ujian semester mata pelajaran bahasa Inggris.

Tabel 2. Rataan Nilai Harian Siswa 4/1

\begin{tabular}{ccc}
\hline $\begin{array}{c}\text { Pertemuan } \\
\text { ke- }\end{array}$ & $\begin{array}{c}\text { Banyaknya } \\
\text { dilaksanakan } \\
\text { program } E B \\
\left(\mathrm{X}_{2}\right)\end{array}$ & $\begin{array}{c}\text { Rataan nilai } \\
\text { harian siswa } \\
\left(\mathrm{Y}_{2}\right)\end{array}$ \\
\hline 1 & 3 & 4,00 \\
2 & 6 & 4,03 \\
3 & 9 & 4,00 \\
4 & 12 & 4,04 \\
5 & 15 & 4,23 \\
6 & 18 & 4,28 \\
7 & 21 & 4,06 \\
8 & 24 & 4,41 \\
9 & 27 & 4,56 \\
10 & 30 & 4,62 \\
11 & 33 & 4,59 \\
12 & 36 & 4,68 \\
13 & 39 & 4,74 \\
14 & 42 & 4,77 \\
\hline & &
\end{tabular}

Menggunakan software minitab 17 dengan $\alpha=0,05$ diperoleh persamaan regresi $Y_{2}=3,85+0,0226 X_{2}$ dengan $R_{S q}=90,5 \%$. Dengan derajat bebas 12 diperoleh $T_{\text {hitung }}=$ $71,06>2.17881=T_{\text {tabel }}$ dan $\quad F_{\text {hitung }}=$ $113,67>4.74723=F_{\text {tabel }}$ yang berarti ada pengaruh $\mathrm{X}$ dengan $\mathrm{Y}$ dan model yang diperoleh berarti. Dari persamaan regresi tersebut diperoleh kemiringan yang bernilai positif. Hal ini dapat disimpulkan bahwa semakin banyak dilakukan $E B$, dampak terhadap hasil KBM di kelas berupa rata-rata nilai harian siswa menjadi meningkat secara signifikan dan stabil.

\section{SIMPULAN}

Pelaksanaan program English Breakfast dapat membantu siswa untuk meningkatkan banyaknya kosa kata bahasa Inggris. Selain itu, program ini melatih siswa mengucapkan kosa kata sesuai dengan kaidah baca dalam bahasa Inggris dengan media yang mudah untuk dibuat. Program ini dilaksanakan secara rutin dalam durasi singkat. Pelaksanaan program ini menghasilkan data-data yang dapat dianalisis menggunakan minitab 17. Dari hasil analisis tersebut program ini mampu meningkatkan kemampuan berbahasa Inggris dan berpengaruh positif terhadap hasil belajar siswa di kelas. Untuk program English Breakfast selanjutnya diharapkan dapat melaksanakannya dengan metode yang menarik dan kreatif supaya tetap mempertahankan minat siswa dalam belajar bahasa Inggris.

\section{DAFTAR PUSTAKA}

Astutie, Y. R. E. (2018). Peningkatan Kemampuan Berbicara Bahasa Inggris Siswa Kelas VII SMP Negeri I Kota Blitar Melalui Games (Kalender). Jurnal Pendidikan, 2(1), 45-56.

Julia, J., Isrok'atun, I., \& Safari, I. (2018). Prosiding Seminar Nasional "Membangun Generasi Emas 2045 yang Berkarakter dan Melek IT" dan Pelatihan "Berpikir Suprarasional." UPI Sumedang Press. https://books.google.co.id/books?hl=en\& $\mathrm{lr}=\& \mathrm{id}=\mathrm{h} 09 \mathrm{KDwAAQBAJ} \& \mathrm{oi}=\mathrm{fnd} \& \mathrm{pg}=$ PR1\&dq=info:obnbM6UFbJUJ:scholar.g oogle.com\&ots=I-

IHT44VIp\&sig=fFxIe5yqsFAk0O9OdeX Qk8p8shY\&redir_esc=y\#v=onepage\&q $\& \mathrm{f}=$ false

Robertson, J. (2017). Mengawali Kegiatan Belajar di Luar Kelas. https://belajardiluarkelas.org/wpcontent/uploads/sites/7/2017/07/MEMUL AI-PEMBELAJARAN-DI-LUARKELAS.pdf

Sunardi, \& Sujadi, I. (2017). Sumber Belajar Calon Peserta PLPG Desain Pembelajaran.

https://www.scribd.com/document/35437 3805/Bab-Viii-Refleksi-PembelajaranDan-Ptk

Utami, I. W. P. (2015). Kemampuan mahasiswa melakukan refleksi dalam 
pembelajaran sejarah. August, 2-3.

Windarti, \& Budiningsih, C. A. (2016). http://journal.uny.ac.id/index.php/jitp. Jurnal Inovasi Teknologi Pendidikan, 3(1), 106-115.

Yarmi, G., \& Atika, V. (2015). Peningkatan Hasil Belajar Vocabulary Melalui Metode Role Playing Dalam Pembelajaran Bahasa Inggris Siswa Kelas Iv Sd Laboratorium Pgsd Fip Unj Jakarta Selatan. Jurnal Ilmiah PGSD, 8(2), 61-67. https://doi.org/10.1017/CBO9781107415 324.004 